\title{
Evaluations of antidepressant activity of Punica granatum peel extract in albino mice
}

\author{
Shakira Fathima Syeda ${ }^{1 *}$, Sam Pavan Kumar G. ${ }^{1}$, Mohammed Mohsin ${ }^{2}$
}

\author{
${ }^{1}$ Department of Pharmacology, Chalmeda Anand Rao Institute of Medical Sciences, Karimnagar, Telangana, India \\ ${ }^{2}$ Department of Pharmacology, Deccan Medical College, Hyderabad, Telangana, India
}

\author{
Received: 10 December 2019 \\ Revised: 06 February 2020 \\ Accepted: 11 February 2020

\section{*Correspondence:} \\ Dr. Shakira Fathima Syeda \\ Email: shakirafathimasyeda@gmail.com
}

Copyright: (C) the author(s), publisher and licensee Medip Academy. This is an open-access article distributed under the terms of the Creative Commons Attribution Non-Commercial License, which permits unrestricted non-commercial use, distribution, and reproduction in any medium, provided the original work is properly cited.

\begin{abstract}
Background: Depression is the most common disorder of mental illnesses and affects excess of $10-15 \%$ of population. According to the WHO reports, more than 350 million persons suffer from depression all over the world. The aim of present study is to evaluate anti-depressant activity of Punica granatum peel extract $(P g P E)$ in albino mice.

Methods: Male albino mice (20-30 g) were used. Animals were divided into 5 groups with 6 animals in each which were subjected to forced swim test. Group 1 is control, group 2 received (standard) imipramine $10 \mathrm{mg} / \mathrm{kg}, \mathrm{p} . \mathrm{o}, \mathrm{group}$ 3 (T1) PgPE $50 \mathrm{mg} / \mathrm{kg}$, p.o, group 4 (T2) PgPE $100 \mathrm{mg} / \mathrm{kg}$, p.o, group 5 (T3) $P g$ PE $200 \mathrm{mg} / \mathrm{kg}$, at first animals were forced to swim for $15 \mathrm{~min}$ (trained), and the study was performed after $24 \mathrm{hrs}$. All the animals were treated with individual drug $60 \mathrm{~min}$ prior to study, animals were forced to swim for $6 \mathrm{~min}$ and the duration of immobility was recorded. The mouse was considered immobile when it floats motionlessly or made only those moments necessary to keep its head above the water surface. The total duration of immobility of each mouse was recorded after the test in each group.
\end{abstract}

Results: The duration of immobility is significantly reduced at $P g P E 200 \mathrm{mg} / \mathrm{kg}$ and results were analysed by one way analysis of variance (ANOVA).

Conclusions: $\operatorname{PgPE} 200 \mathrm{mg} / \mathrm{kg}$ significantly $(\mathrm{p}<0.05)$ decreases the duration of immobility in mice.

Keywords: Punica granatum peel extracts, Antidepressant, Forced swim test

\section{INTRODUCTION}

Depression is the most common disorder of mental illnesses and affects excess of $10-15 \%$ of population. Depressive disorders are amenable to pharmacology treatment, developed since the 1950s. ${ }^{1}$ Patients with depressed mood experience a loss of energy and interest, feelings of guilt, difficulty in concentrating, loss of appetite, libido, and thoughts of suicide. ${ }^{2}$ Prevalence of the depression is about $10-25 \%$ in females and $5-12 \%$ in males. ${ }^{3}$ According to the WHO reports, more than 350 million persons suffer from depression all over the world. Approximately two thirds of depression patient's experience suicidal thoughts $10-15 \%$ of them being dead from suicide before the age of $40 .{ }^{4}$ Many of these patients being unaware of their disease do not receive any medications. Several synthetic antidepressant drugs are available in pharmaceutical markets; however, their effectiveness is not satisfactory along with undesirable side effects such as dry mouth, hypotension, fatigue, sexual dysfunction and drowsiness as well as drug interactions as the major restrictions for the clinical utility. ${ }^{5}$ People from different regions of the world have 
been used medicinal herbs to alleviate disorders for many years and the entrance of new herbal medicines in the pharmaceutical industry has been hot topics in the last decades. $^{6}$

Over the past decade, pomegranate (Punica granatum) is titled as a wonder fruit because of its voluminous pharmacological properties. In 1830, Punica granatum fruit was first recognized in United States Pharmacopeia; the Philadelphia edition introduced the rind of the fruit was introduced. There are significant efforts and progress made in establishing the pharmacological mechanisms of peel (pericarp or rind) and the individual constituents responsible for them. However, the medicinal properties of Punica granatum as a fruit peel have very scantily studies. The CNS activity of Punica granatum peel extract is less touched field and there are rare reports on antidepressant activity of Punica granatum. Hence the present study was planned.

This review provides an insight on the phytochemical components that contribute too on nephroprotective by Nidhal et al, hepatoprotective by Eshwaraiah et al, antidiabetic by Enas et al, antioxidant by Gurpreet et al, anti-angiogenesis by Dana et al, analgesic and antiinflammatory by Mithun et al, anti-cancer activity by Lansky, anti-diarrheal activity by Qnais et al, antibiotic resistance by Shaza et al and antiproliferation by Mehmet, of Punica granatum have been reported. ${ }^{7-16}$ These phytochemical components contribute wonderful, economic and eco-friendly effects of pomegranate peel extract. ${ }^{17}$ The antidepressant activity of Punica granatum is mentioned in the Indian system of traditional medicine, but there is a rare scientific evidence to prove its activity by Shamima et al. ${ }^{18}$ Hence, the present study is designed to evaluate the antidepressant activity of Punica granatum peel extract using animal models in mice was planned.

\section{Botanical classification}

- Kingdom: Plantae

- Division: Magnoliophyta

- Class: Magnoliopsida

- Order: Myrtales

- Family: Punicaceae

- Genus: Punica L.

- Species: Punica granatum L.

The dried peel of Punica granatum L. is extensively used in Ayurvedha, Siddha and Chinese medicinal systems. Different parts of the tree like Roots, Bark, Flowers, Fruit, Fruit peel, Pulp and Seeds.

\section{Aim of the study}

The aim of present study is to evaluate anti-depressant activity of Punica granatum peel extract in albino mice.

\section{METHODS}

\begin{abstract}
Animals
Male albino mice of weighing 20-30 grams were used in this study; laboratory bred albino mice were obtained from M/S Sainath Agencies, Hyderabad and placed in individual cages in central animal house of department of Pharmacology, Chalmeda Anand Rao Institute of Medical sciences, Bommakal, Karimnagar, Telangana, the animals were stabilized for 1 week under standard conditions at temperature $25 \pm 1^{\circ} \mathrm{C}, \quad 60 \pm 5 \%$ relative humidity and $12 \mathrm{hrs}$ dark light cycles. They had been given free accesses to standard pellet diet and water ad libitum. The study was conducted according to the ethical norms approved by the IAEC, and was carried out in accordance with the recommendations of CPCSEA. Ref: CAIMS/IAEC/Research Project/Lr/04/2016/CPCSEA.
\end{abstract}

\section{Acute oral toxicity study}

The Punica granatum peel ethanolic ( $P g \mathrm{PE})$ extract were found to be safe up to the dose level of $2000 \mathrm{mg} / \mathrm{kg}$, p.o., and did not produce any toxic symptoms. The survived animals were sacrificed, and complete absorption of the drug through gastrointestinal tract was observed. Hence, $1 / 20$ th and 1/10th of maximum therapeutic dose (2000 $\mathrm{mg} / \mathrm{kg}$ ) were selected for the pharmacological models.

Solvents: Normal saline and distilled water were used.

Plant material: Punica granatum peels extract (PgPE).

Drug: Imipramine (Depsonil).

\section{Instruments}

Syringes $(2 \mathrm{ml}$ and $5 \mathrm{ml}$ ), tuberculin syringes, infant feeding tube and beakers.

Apparatus: Aquarium $(25 \times 18 \times 25 \quad \mathrm{~cm})$, weighing machine and stop watch.

Miscellaneous: Measuring jar, marking pens and cotton.

\section{Preparation of extract}

Pomegranate fruit were collected from local market of Karimnagar, and they were identified by the HOD, Department of Botany, S.R.R. Degree and P.G. College of Sciences, Karimnagar. Pomegranate fruit peel were manually separated, shade dried and grounded to coarse particles weighing 250 grams underwent 8 cycles of extraction which was carried out with Soxhlet apparatus using 50\% ethanol. The extracts were pooled and concentrated under vaccum at $45^{\circ} \mathrm{C} .{ }^{19}$ 


\section{Experimental design}

Male albino mice of weighing 20-30 grams were used. Animals were divided into 5 groups with 6 animals in each which were subjected to forced swim test (FST). Group 1 (control) received distilled water $10 \mathrm{ml} / \mathrm{kg}$, p.o, group 2 (standard) received imipramine $10 \mathrm{mg} / \mathrm{kg}$, p.o, group 3 (test 1), group 4 (test 2) and group 5 (test 3) received ethanolic peel extract of Punica granatum i.e., $50 \mathrm{mg} / \mathrm{kg}, 100 \mathrm{mg} / \mathrm{kg}$ and $200 \mathrm{mg} / \mathrm{kg}$, p.o. respectively. ${ }^{20}$ All group animals were individually forced to swim in an open aquarium $(25 \times 18 \times 25 \mathrm{~cm})$ containing $18 \mathrm{~cm}$ of water at $25^{\circ} \mathrm{C}$. At first animals were forced to swim for $15 \mathrm{~min}$ (trained), and the study was performed after $24 \mathrm{hrs}$. All the animals were treated with individual drug $60 \mathrm{~min}$ prior to study, animals were forced to swim for 6 min and the duration of immobility was recorded. The mouse was considered immobile when it floats motionlessly or made only those moments necessary to keep its head above the water surface (Figure 1). Animals were removed from water, dried with a clean towel and placed back in cages. The water was changed after each test. The total duration of immobility of each mouse was recorded after the test in each group. ${ }^{21,22}$ After completion of forced swim test animals were transferred back to the central animal house.

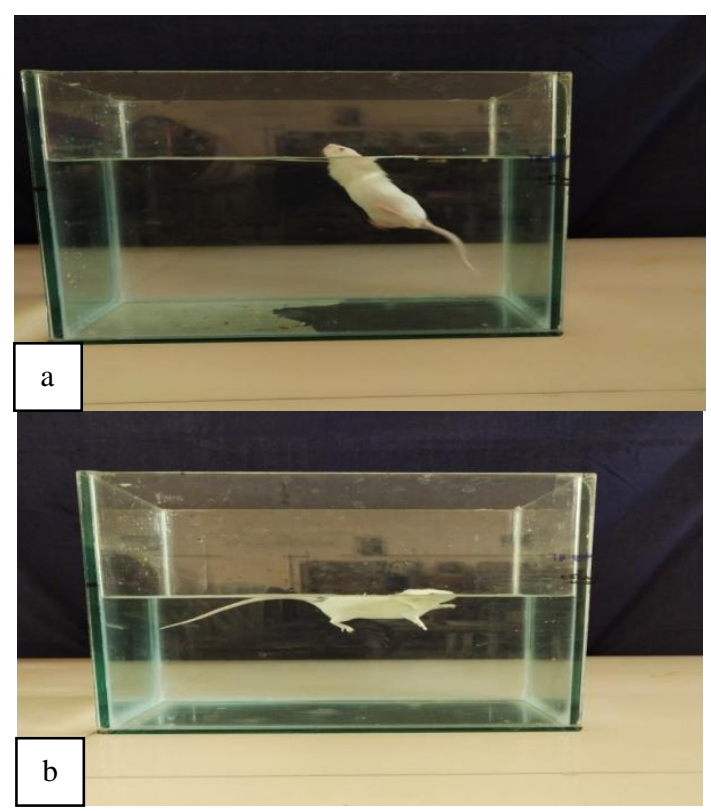

Figure 1: (a) Mobility and (b) immobility of mouse in aquarium.

Observations were recorded and results were analysed by one way analysis of variance (ANOVA). ${ }^{23}$

\section{RESULTS}

In this current study, the results obtained in the FST are mild significant at a dose of $100 \mathrm{mg} / \mathrm{kg}$ where as it is highly statistically significant at dose of $200 \mathrm{mg} / \mathrm{kg}$ (Table 1 and Figure 2). Animals after antidepressant treatment struggle more even in desperate situation, and they spend less time with immobility. Results showed that Punica granatum peel extract produces a diminution of the duration of immobility time of animals when exposed to FST.

Punica granatum peel extract significantly $(\mathrm{p}<0.05)$ decreases the duration of immobility in mice.

Table 1: Result of FST.

\begin{tabular}{|lll|}
\hline Groups & Parameters & \multicolumn{1}{c}{$\%$ of immobility } \\
\hline $\begin{array}{l}\text { Normal } \\
\text { (control) }\end{array}$ & Mean \pm SD & $2.27 \pm 0.64$ \\
\cline { 2 - 3 } $\begin{array}{l}\text { Standard } \\
\text { (imipramine) }\end{array}$ & Mean \pm SD & - \\
\hline \multirow{2}{*}{ Test $\mathbf{1}$} & SEM & $1.76 \pm 0.40^{* *}$ \\
\hline \multirow{2}{*}{ Test 2 } & Mean \pm SD & 0.166 \\
\cline { 2 - 3 } & SEM & $0.19 \pm 0.28$ \\
\hline \multirow{2}{*}{ Test 3 } & Mean \pm SD & $2.13 \pm 0.31^{*}$ \\
\cline { 2 - 3 } & SEM & 0.12 \\
\hline Mean \pm SD & $1.96 \pm 0.23^{* *}$ \\
\hline
\end{tabular}

All the values are expressed as mean \pm SEM of all group animals. $*$ P value $<0.05, * * \mathrm{P}$ value $<0.01$.

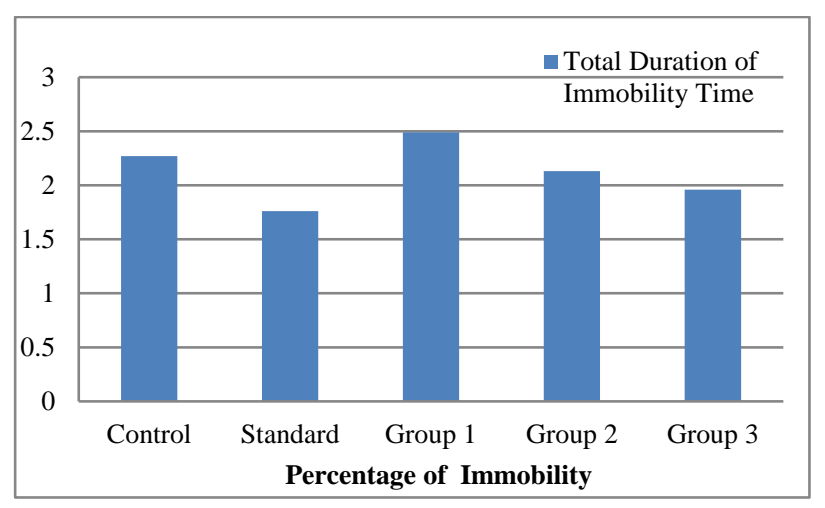

Figure 2: Total duration of immobility time.

\section{DISCUSSION}

The current study is a behavioral studies where when a normal animal is submitted to a difficult or inescapable situation; it alternates between two kinds of behavior that is agitation and immobility. Intense motor activity and expense of energy such as struggling and body jerks are named as searching-behavior. Whereas, immobility and energy saving, in studies i.e., when the animal stops struggling is characterized as waiting-behavior, and it is assumed that antidepressant effect is in favor of the searching behaviour. ${ }^{24}$ Present study, FST model play an important role in the evaluation and development of antidepressant drugs. ${ }^{25}$ In the present study, the $P g \mathrm{PE}$ (200 $\mathrm{mg} / \mathrm{kg}$, p.o.) administered to mice produced significant antidepressant effect in FST and its efficacies were found to be comparable to imipramine $(10 \mathrm{mg} / \mathrm{kg}$, p.o.) (Table 1 and Figure 2). From all the above, the antidepressant activity of $P g \mathrm{PE}$ was found to be 
significant at $200 \mathrm{mg} / \mathrm{kg}$, p.o. A few authors have studied the antidepressant activity of some of the chemical components present in Punica granatum peel. Dhingra et al and Naveen et al reported the antidepressant-like activity of ellagic acid, polyphenols and omega-3 fatty acid respectively from pomegranate peel, in mice. ${ }^{26,27}$ Abdul et al reported the antidepressant like activity of polyphenols respectively from Punica granatum methanolic extract in mice. ${ }^{18}$

From the discussion it is suggested that Punica granatum peel extract flavonoids and polyphenols components might produce antidepressant effect by interaction with adrenergic receptor there by increasing the level of noradrenaline along with reduction in level of serotonin and dopamine in brains of mice. This showed that $P g P E$ has an antidepressant like effect but further molecular study should be investigated to confirm it.

\section{CONCLUSION}

The ethanolic extract of Punica granatum peel extract at the dose of $(200 \mathrm{mg} / \mathrm{kg})$ has shown significant antidepressant activity when compared to the control. Amongst all the groups imipramine has good stability and activity. Peel extract of Punica granatum has shown significant antidepressant activity in forced swim test (FST).

\section{Funding: No funding sources}

Conflict of interest: None declared

Ethical approval: The study was approved by the Institutional Ethics Committee

\section{REFERENCES}

1. Goodman and Gilman's. The Pharmacological Basics of Therapeutics. 12th edition. New York NY: McGraw Hill Education; 2011.

2. Kaplan and Ssdock's synopsis of Psychiatry. 10th edition. 2009: 527.

3. Moallem S, Hosseinzadeh $\mathrm{H}$, Ghoncheh $\mathrm{H}$. Evaluation of antidepressant effects of aerial parts of Echium vulgare on mice. Iran $\mathbf{J}$ Basic Med Sci. 2007;10(3):189-96.

4. Mirshafa SA, Azadbakht M, Ahangar N. Study of antidepressant and sedativehypnotic activity of hydroalcoholic extract of Asperugo procumbens L. aerial parts in mice. Iran $\mathbf{J}$ Pharm Res. 2013;12(3):529-35.

5. Sravani K, Sivrama Krishna K. Antidepressant and antioxidant activity of methanolic extract of Asparagus racemosus seeds. Asian J Pharm Clin Res. 2013;16(1):102-7.

6. Zhang ZJ. Therapeutic effects of herbal extracts and constituents in animal models of psychiatric disorders. Life Sci. 2004;75(14):1659-99.

7. Nidhal AK, Mohammed Ali, Sayeed SZ. NephroProtective Effect of Punica granatum peel in
Gentamicin-Induced Nephrotoxicity in Rats. Med J Babylon. 2012;9(1):220-8.

8. Eshwaraiah MC, Manasa N, Kavitha K, Bardalal D. Evaluation of Hepatoprotective activity of Ethanolic extract of Punica granatum. Int J Pharm Pharmaceut Sci. 2013;5(4):220-3.

9. Khalil EAM. Antidiabetic effect of an aqueous extract of Pomegranate (Punica granatum L.,) peels in normal and alloxan diabetic rats. Egyptian $\mathbf{J}$ Hosptial Med. 2004;16:92-9.

10. Kauraur G, Jabbar G, Athar Z, Alam M, Sarwar Alam M. Punica granatum (Pomegranate) flower extract possesses potent antioxidant activity and abrogates. Fe-NTA induced hepatotoxicity in mice. Food Chem Toxicol. 2006;44(7):984-93.

11. Nasim D, Javanmard SH, Rafiee L. Anti-Angiogenic Effects of Pomegranate Peel Extract (Punica Granatum L.) on Human Umbilical Vein Endothelial Cells. J Isfahan Med School. 2012;30(195):919-21.

12. Sarker M, Das SC, Saha SK, Al Mahmud Z, Bachar SC. Analgesic and Anti-inflammatory Activities of Flower Extracts of Punica granatum Linn. (Punicaceae). J Appl Pharmaceut Sci. 2012;12:133-6.

13. Lansky EP, Newman RA. Punica granatum (pomegranate) and its potential prevention and treatment of inflammation and cancer. $\mathbf{J}$ Ethnopharmacol. 2007;109(2):177-206.

14. Qnais EY, Elokda AS, Abu Ghalyun YY, Abdulla FA. Antidiarrheal Activity of the Aqueous Extract of Punica granatum (Pomegranate) peels. Pharmaceut Biol. 2007;45(9):715-20.

15. Al Laham SA, Al Fadel FM. The Anti-Bacterial Effect of Punica granatum Extracts Against Antibiotic Resistant Pasteurella haemolytica. Jundishapur J Microbiol. 2013;6(9):1-16,20.

16. Karaaslan M, Vardin H, Varliklioz S, Yilmaz FM. Antiproliferative and antioxidant activities of Turkish pomegranate (Punica granatum L.) accessions. Int $\mathbf{J}$ Food Sci. 2014;49(1):82-90.

17. Middha SK, Usha T, Pande V. A review on antihyperglycemic and antihepatoprotective activity of Eco-friendly Punica granatum peel waste Evi Based Complemen Alternat Med. 2013;2013:656172.

18. Rahman A, Kadar SA, Baharuldin B, Hidayat MT, Moklas M, Aris M. Antidepressant like effect of methanolic extract of Punica granatum (Pomegranate) in mice model of depression. J Nat Prod Biomed Res. 2015;1(1):16-20.

19. Ghosh MN. Fundamentals of Experimental Pharmacology. 6th Edition. 2015: 297p.

20. Vogel HG, Drug Discovery and Evaluation, Pharmacological Assays Second Edition, Volume II. Springer; 2002: 559-561.

21. Gupta SK. Drug Screening Methods. 2016; 78.

22. Porsolt RD, Bertin A, Jalfre M. Behavioral despair in mice: screening test for antidepressants. Arch Int Pharmacodynamics. 1977;229(2):327-36.

23. McDonald JH. Handbook of Biological Statistics. Baltimore; Sparky House Publishing; 2008. 
24. Steru L, Chermat R, Thierry B, Simon P. The tail suspension test: A new method for screening antidepressants in

mice. Psychopharmacology.1985;85(3):367-70.

25. Qun X, Li-Tao Y, Ying P, Xing W, Yu-Cheng L, Jian-Mei L, et al, Antidepressant-like effects of the mixture of honokiol and magnolol from the barks of Magnolia officinalis in stressed rodents. Progress in Neuro-Psychopharmacol Biol Psych. 2008;32(3):715-25.

26. Dhingra D, Chhillar R. Antidepressant-like activity of ellagic acid in unstressed and acute immobilization-induced stressed mice. Pharmacol Rep. 2012;64(4):796-807.

27. Naveen S, Siddalingaswamy M, Singsit D, Khanum F. Anti-depressive effect of polyphenols and omega-3 fatty acid from pomegranate peel and flax seed in mice exposed to chronic mild stress. Psychiatry Clin Neurosci. 2013;67(7):501-8.

Cite this article as: Syeda SF, Sam PKG, Mohsin M. Evaluations of antidepressant activity of Punica granatum peel extract in albino mice. Int J Basic Clin Pharmacol 2020;9:449-53. 